\title{
Potentiation of Quantal Catecholamine Secretion by Glibenclamide: Evidence for a Novel Role of Sulphonylurea Receptors in Regulating the $\mathrm{Ca}^{2+}$ Sensitivity of Exocytosis
}

\author{
S. C. Taylor, ${ }^{1}$ E. Carpenter, ${ }^{1}$ M. L. Roberts, ${ }^{2}$ and C. Peers ${ }^{1}$ \\ 1/nstitute for Cardiovascular Research, University of Leeds, Leeds LS2 9JT, United Kingdom, and 2Department of \\ Physiology, University of Adelaide, Adelaide 5005, Australia
}

Electrochemical detection of quantal catecholamine release from PC-12 cells revealed that glibenclamide, an inhibitor of ATP-sensitive $\mathrm{K}^{+}$channels, potentiated $\mathrm{Ca}^{2+}$-dependent exocytosis evoked by raised extracellular $\left[\mathrm{K}^{+}\right]$and by exposure of cells to caffeine. Glibenclamide was without effect on voltagegated $\mathrm{Ca}^{2+}$ currents, membrane potential, or rises of $\left[\mathrm{Ca}^{2+}\right]_{i}$ evoked by either raised extracellular $\left[\mathrm{K}^{+}\right]$or caffeine. The dependence of $\mathrm{K}^{+}$-evoked secretion on extracellular $\mathrm{Ca}^{2+}$ was shifted leftward in the presence of glibenclamide, with a small increase in the plateau level of release, suggesting that gliben- clamide primarily increased the $\mathrm{Ca}^{2+}$ sensitivity of the exocytotic apparatus. Enhancement of secretion by glibenclamide was reversed by pinacidil and cromakalim, indicating that the effects of glibenclamide were mediated via an action on a sulfonylurea receptor. These results demonstrate that sulfonylurea receptors can modulate $\mathrm{Ca}^{2+}$-dependent exocytosis via a mechanism downstream of $\mathrm{Ca}^{2+}$ influx or mobilization.

Key words: glibenclamide; sulfonylurea; catecholamines; exocytosis; $\mathrm{Ca}^{2+}$; amperometry; $K_{\text {ATP }}$ channel; pheochromocytoma
ATP-sensitive $\mathrm{K}^{+}$channels $\left(\mathrm{K}_{\mathrm{ATP}}\right.$ channels) are now established as octomeric proteins, consisting of four inward rectifier $\mathrm{K}^{+}$ channel subunits (most likely of the $\mathrm{K}_{\mathrm{IR}}$ 6.x family) associated with four sulfonylurea receptors (SURs) (for review, see AguilarBryan et al., 1998). SURs are the binding sites for known blockers (e.g., glibenclamide) and activators (e.g., pinacidil and cromakalim) of these channels, which have found valuable therapeutic uses. $\mathrm{K}_{\mathrm{ATP}}$ channels are classically identified as being inhibited by intracellular ATP and were first described in cardiac myocytes (Noma, 1983) in which they were believed to act under conditions of metabolic stress to shorten action potential durations and so reduce the energy demands of myocytes when intracellular ATP levels are reduced (Benndorf et al., 1997).

$\mathrm{K}_{\mathrm{ATP}}$ channels have since been identified in numerous different tissues, including central neurons (Ashford et al., 1988; Murphy and Greenfield, 1992; Finta et al., 1993; Pierrefiche et al., 1996). Their role in the normal functioning of neuronal activity is not well established, but they have been shown to alter electrical excitability (primarily by causing membrane hyperpolarization when open) under hypoxic or ischemic conditions (Murphy and Greenfield, 1992; Wu et al., 1996). More recently, evidence has emerged that $\mathrm{K}_{\mathrm{ATP}}$ channels may be active under normoxic conditions when intracellular ATP levels would not be expected to be depleted (Pierrefiche et al., 1996). Furthermore, application of the sulfonylureas tolbutamide and glibenclamide have revealed that $\mathrm{K}_{\mathrm{ATP}}$ channels influence the release of acetylcholine from rat striatal slices in vitro (Lee et al., 1997).

Extensive studies of transmitter release have demonstrated the complex interaction of an array of membrane and vesicular pro-

\footnotetext{
Received April 12, 1999; accepted April 28, 1999.

This work was supported by The British Heart Foundation and The Wellcome Trust.

Correspondence should be addressed to Dr. Chris Peers, Institute for Cardiovascular Research, University of Leeds, Leeds LS2 9JT, UK.

Copyright (C) 1999 Society for Neuroscience $0270-6474 / 99 / 195741-09 \$ 05.00 / 0$
}

teins (Sudhof, 1995; Hanson et al., 1997). Such studies have in recent years been advanced by the real-time monitoring of exocytosis in a variety of cell types (for review, see Angleson and Betz, 1997). One such technique is that of amperometry, which is used to monitor release of individual quanta of oxidizable transmitter species, such as catecholamines and indolamines (Chow and Von Ruden, 1995). We have used this technique to study catecholamine secretion from the rat pheochromocytoma cell line PC-12, which has been used extensively as a model secretory cell system. In particular, we have investigated a potential role for $\mathrm{K}_{\mathrm{ATP}}$ channels in regulating evoked catecholamine secretion. Using both inhibitors and activators of $\mathrm{K}_{\mathrm{ATP}}$ channels, we report here a novel functional effect of glibenclamide to enhance catecholamine release via an action on sulfonylurea receptors that cannot be accounted for by effects on membrane potential or $\mathrm{Ca}^{2+}$ influx.

\section{MATERIALS AND METHODS}

Cell culture. PC-12 cells (from the American Tissue Type Cell Collection, Rockville, MD) were thawed rapidly at $37^{\circ} \mathrm{C}$ from storage aliquots kept in liquid nitrogen and diluted 1:5 with RPMI 1640 culture medium (containing L-glutamine). Medium was supplemented with $20 \%$ fetal calf serum and $1 \%$ penicillin-streptomycin (Life Technologies, Paisley, Strathclyde, UK) and incubated at $37^{\circ} \mathrm{C}$ for $24 \mathrm{hr}$ in a humidified atmosphere of $5 \% \mathrm{CO}_{2}-95 \%$ air. After this period, cells in suspension culture (at a density of $0.5-1.0 \times 10^{6}$ cells $/ \mathrm{ml}$ ) were removed from the flask, centrifuged at $70 \times g$ for $10 \mathrm{~min}$, resuspended in fresh medium, and reseeded in flasks at 1:5 dilution. This preparation of cells was designated passage 1, and cells were used for experiments for up to 20 passages. Each passage was conducted after $7 \mathrm{~d}$ when the cells were resuspended in fresh medium and diluted 1:2. The prolonged period without medium change enhanced evoked catecholamine release (Takashima and Koike, 1985). Cells used for experiments were transferred to smaller flasks in 10 $\mathrm{ml}$ of medium and $1 \mu \mathrm{M}$ dexamethasone (from a stock solution of $1 \mathrm{~mm}$ in Ultrapure water; Sigma, Poole, UK) was applied for 72-96 hr to enhance catecholamine secretion further (Tischler et al., 1983).

On each experimental day, aliquots of PC-12 cells were plated onto poly-D-lysine-coated $22 \times 22 \mathrm{~mm}$ coverslips at a density of $0.5-1.0 \times 10^{5}$ 


\section{A $5 \mathrm{mMK} K^{+}$}

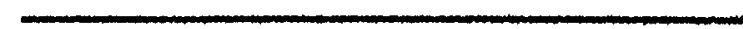

C $50 \mathrm{mM} \mathrm{K}^{+}$

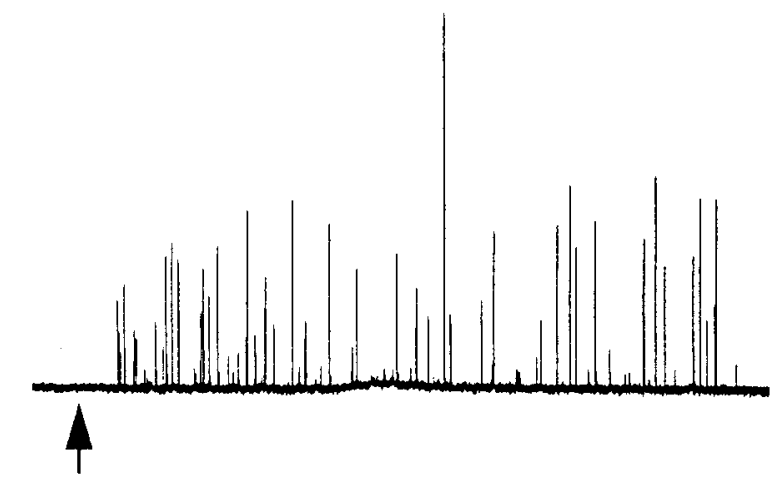

$\mathrm{E}$
B + glibenclamide

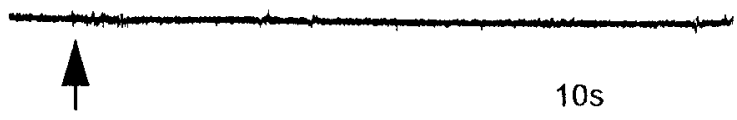

$10 \mathrm{~s}$

$\mathrm{D}+$ glibenclamide
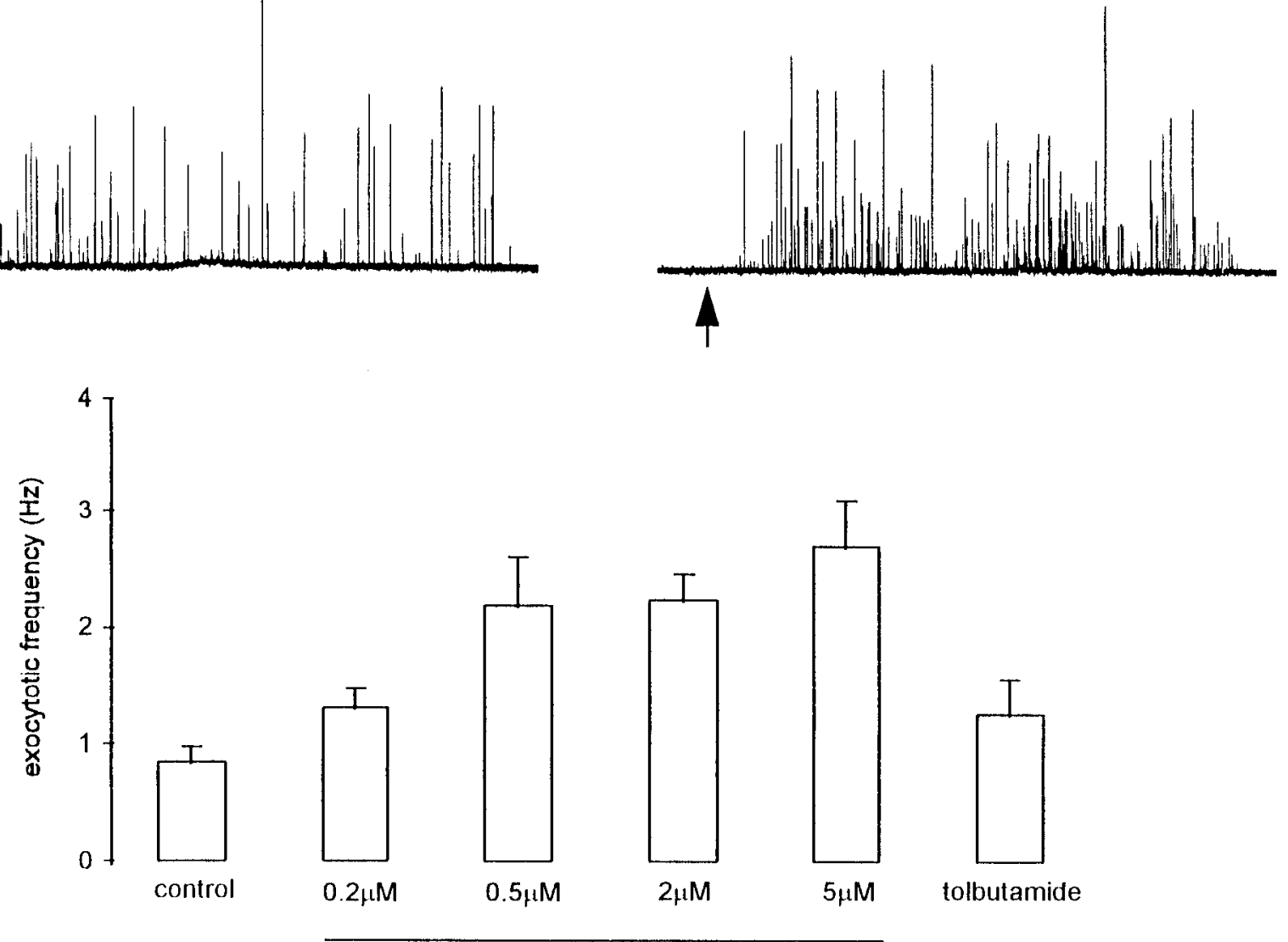

glibenclamide

Figure 1. $A-D$, Amperometric recordings from individual PC-12 cells using polarized $(+800 \mathrm{mV})$ carbon fiber microelectrodes $(5 \mu \mathrm{m}$ diameter $)$. Cells were perfused with a solution containing either $5(A, B)$ or $50(C, D) \mathrm{mM} \mathrm{K}^{+}$in the absence $(A, C)$ or presence $(B, D)$ of $0.5 \mu \mathrm{M}$ glibenclamide. Arrows in $B-D$ indicate the point at which solutions was exchanged; there was a $6 \mathrm{sec}$ time lag before the test solution reached the recording chamber because of dead volume of the perfusion system. Calibration applies to all traces. E, Bar graph illustrating frequency of occurrence of exocytotic events evoked by $50 \mathrm{mM} \mathrm{K}^{+}$in the absence (control) or presence of glibenclamide (concentrations as indicated) or in the presence of $0.5 \mathrm{~mm}$ tolbutamide. Each bar shows mean \pm SEM exocytotic frequency determined from between 8 and 13 cells.

cells per coverslip and allowed to adhere for $\sim 1 \mathrm{hr}$. For all experiments, fragments of coverslip were then transferred to a recording chamber (volume of $\sim 80 \mu \mathrm{l}$ ), which was continually perfused under gravity (flow rate of $1-2 \mathrm{ml} / \mathrm{min}$ ) with a control solution containing (in $\mathrm{mM}$ ): $\mathrm{NaCl} 135$, $\mathrm{KCl} 5, \mathrm{MgSO}_{4} 1.2, \mathrm{CaCl}_{2}$ 2.5, HEPES 5, and glucose $10, \mathrm{pH} 7.4$ (osmolarity adjusted to $\sim 300 \mathrm{mOsm}$ with sucrose at $21-24^{\circ} \mathrm{C}$ ). $\mathrm{Ca}^{2+}$-free solutions contained $1 \mathrm{~mm}$ EGTA and no added $\mathrm{Ca}^{2+}$. All drugs were applied in the perfusate, and solution exchange involved a 6 sec delay because of the dead volume of the perfusion tubing. For experiments in which the perfusate $\left[\mathrm{K}^{+}\right]$was raised to $50 \mathrm{mM}$, the extracellular $\left[\mathrm{Na}^{+}\right]$ was reduced by the same amount to maintain iso-osmolarity.

Amperometry. Carbon fiber microelectrodes (proCFE; Axon Instruments, Foster City, CA) with a diameter of $5 \mu \mathrm{m}$ were positioned adjacent to individual PC-12 cells using a Narishige (Tokyo, Japan) MX-2 micromanipulator and were polarized to $+800 \mathrm{mV}$ to allow oxidation of released catecholamine. Resulting currents were recorded using an Axopatch 200A amplifier (with extended voltage range; Axon Instruments), filtered at $1 \mathrm{kHz}$ and digitized at $2 \mathrm{kHz}$ before storage on computer. All acquisition was performed using a Digidata 1200 interface and Fetchex software from the pClamp 6.0.3 suite (Axon Instruments). Exocytosis is expressed as the frequency of quantal events; frequency was determined by counting the number of events over a $55 \mathrm{sec}$ period, $5 \mathrm{sec}$ after switching to test solutions, using Mini Analysis Program (Synaptosoft Inc., Leonia, NJ). The same software allowed quantification of quantal size by integration of each event to obtain charge $Q$, as described previously (Finnegan et al., 1996): $Q=n F C V$, where $n$ is the number of electrons released on oxidation of a catecholamine molecule ( $n=2$ for both dopamine and noradrenaline), $F$ is Faraday's constant, $C$ is the concentration of catecholamine in the vesicle, and $V$ is the vesicle volume. Thus, if $C$ is assumed constant, $Q$ is proportional to $V$, and so $Q^{1 / 3}$ (see Fig. 3) is proportional to vesicle radius.

Electrophysiology. $\mathrm{Ca}^{2+}$ channel currents were recorded using either the whole-cell or perforated-patch technique. In each case, the perfusate was of composition (in $\mathrm{mM}$ ): $\mathrm{NaCl} 110, \mathrm{CsCl} 5, \mathrm{MgCl}_{2} 0.6, \mathrm{BaCl}_{2} 20$, HEPES 5, glucose 10, and tetraethylammonium-Cl 20, $\mathrm{pH} 7.4$. Osmolarity of the perfusate was adjusted to $300 \mathrm{mOsm}$ by addition of sucrose. 


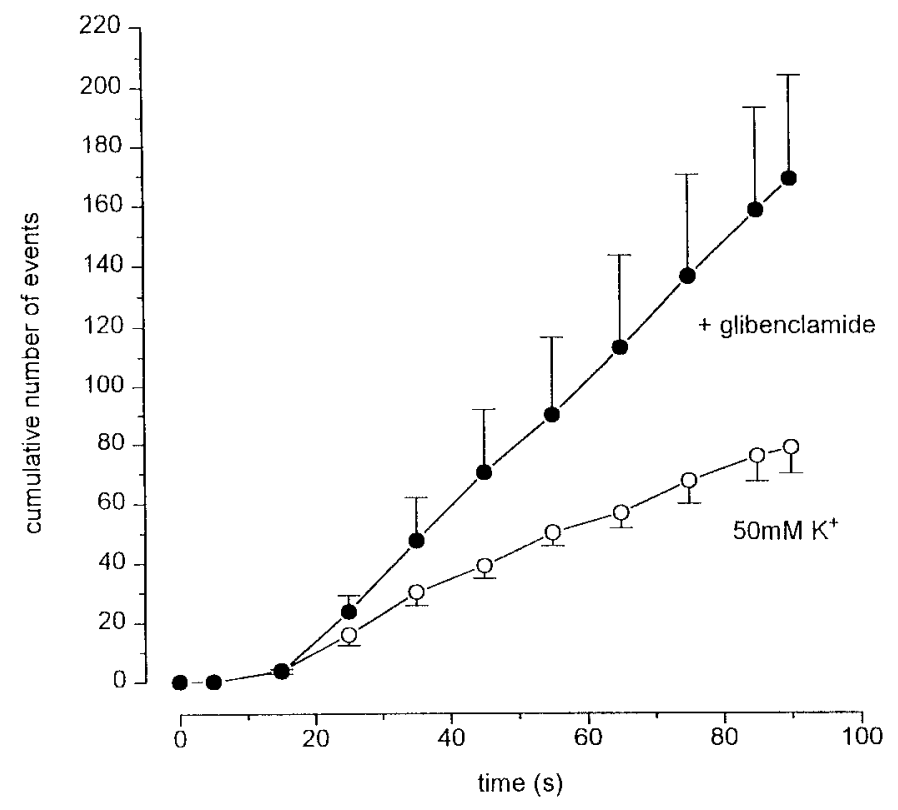

Figure 2. Plot of mean \pm SEM cumulative number of exocytotic events evoked by exposure of cells to $50 \mathrm{mM} \mathrm{K}^{+}$in the absence (open circles; $n=$ 9 cells) and presence ( filled circles; $n=8$ ) of $0.5 \mu \mathrm{M}$ glibenclamide. Test solutions were applied at $t=5 \mathrm{sec}$.

Patch pipettes (5-7 $\mathrm{M} \Omega$ resistance) were filled with a solution containing (in mM): $\mathrm{CsCl} 130$, EGTA 1.1, $\mathrm{MgCl}_{2} 2, \mathrm{CaCl}_{2}$ 0.1, $\mathrm{NaCl} 10$, HEPES 10, and $\mathrm{Na}_{2} \mathrm{ATP}$ 2, $\mathrm{pH}$ 7.2. For perforated-patch recordings, ATP was omitted from the pipette solution and was replaced with amphotericin (final concentration of $240 \mu \mathrm{g} / \mathrm{ml}$, from a stock solution of $60 \mathrm{mg} / \mathrm{ml}$ in dimethylsulfoxide). To investigate any possible effects of glibenclamide on holding current, cells were perfused with the control solution used for amperometric recordings (containing $5 \mathrm{mM} \mathrm{K}^{+}$), and perforated-patch recordings were made using pipettes filled with (in $\mathrm{mM}$ ): $\mathrm{KCl} 120, \mathrm{CaCl}_{2}$ $1, \mathrm{MgSO}_{4} 2, \mathrm{NaCl} 10$, EGTA 11, HEPES 11, and amphotericin 240 $\mu \mathrm{g} / \mathrm{ml}, \mathrm{pH} 7.2$.

$\left[\mathrm{Ca}^{2+}\right]_{i}$ measurements. Cells were preincubated for $1 \mathrm{hr}$ at $21-24^{\circ} \mathrm{C}$ in control solution containing $4 \mu \mathrm{M}$ fura-2 AM. Samples were then placed in the perfusion chamber, and changes in $\left[\mathrm{Ca}^{2+}\right]_{\mathrm{i}}$ were indicated from the fluorescence emitted at $510 \mathrm{~nm}$ as a result of alternate excitation at 340 and $380 \mathrm{~nm}$ using Joyce Loebl PhoCal apparatus (Applied Image, Inc., Rochester, NY). Because calibration of fluorescence into absolute $\left[\mathrm{Ca}^{2+}\right]_{\mathrm{i}}$ values can be subject to artifactual inaccuracies (Duchen, 1992), data are presented as ratio signals.

All data are expressed as means \pm SEM, and statistical comparisons were made using unpaired $t$ tests, with $p<0.05$ being considered significant.

\section{RESULTS}

Figure 1 shows that PC-12 cells do not undergo exocytosis when perfused with a solution containing $5 \mathrm{mM} \mathrm{K}^{+}$and $2.5 \mathrm{mM} \mathrm{Ca}^{2+}$ (Fig. 1A). Bath application of glibenclamide was without effect on exocytosis under these conditions (Fig. 1B). Our previous work (Taylor and Peers, 1998) has demonstrated that raising extracellular $\left[\mathrm{K}^{+}\right]$produces a concentration-dependent increase in the frequency of exocytotic events. Figure $1 C$ illustrates the effect of $50 \mathrm{~mm} \mathrm{~K}^{+}$on secretion, and further raising the $\left[\mathrm{K}^{+}\right]$to $100 \mathrm{~mm}$ produces no further significant increase in the frequency of exocytosis (Taylor and Peers, 1998). In the presence of glibenclamide $(0.5 \mu \mathrm{M})$, secretion evoked by $50 \mathrm{mM} \mathrm{K}^{+}$was dramatically enhanced (Fig. 1D). The potentiating effects of glibenclamide were concentration-dependent, as illustrated in Figure $1 E$. At a high concentration of $0.5 \mathrm{~mm}$, tolbutamide (another sulfonylurea) tended to enhance secretion, but this was not statistically significant (Fig. 1E).
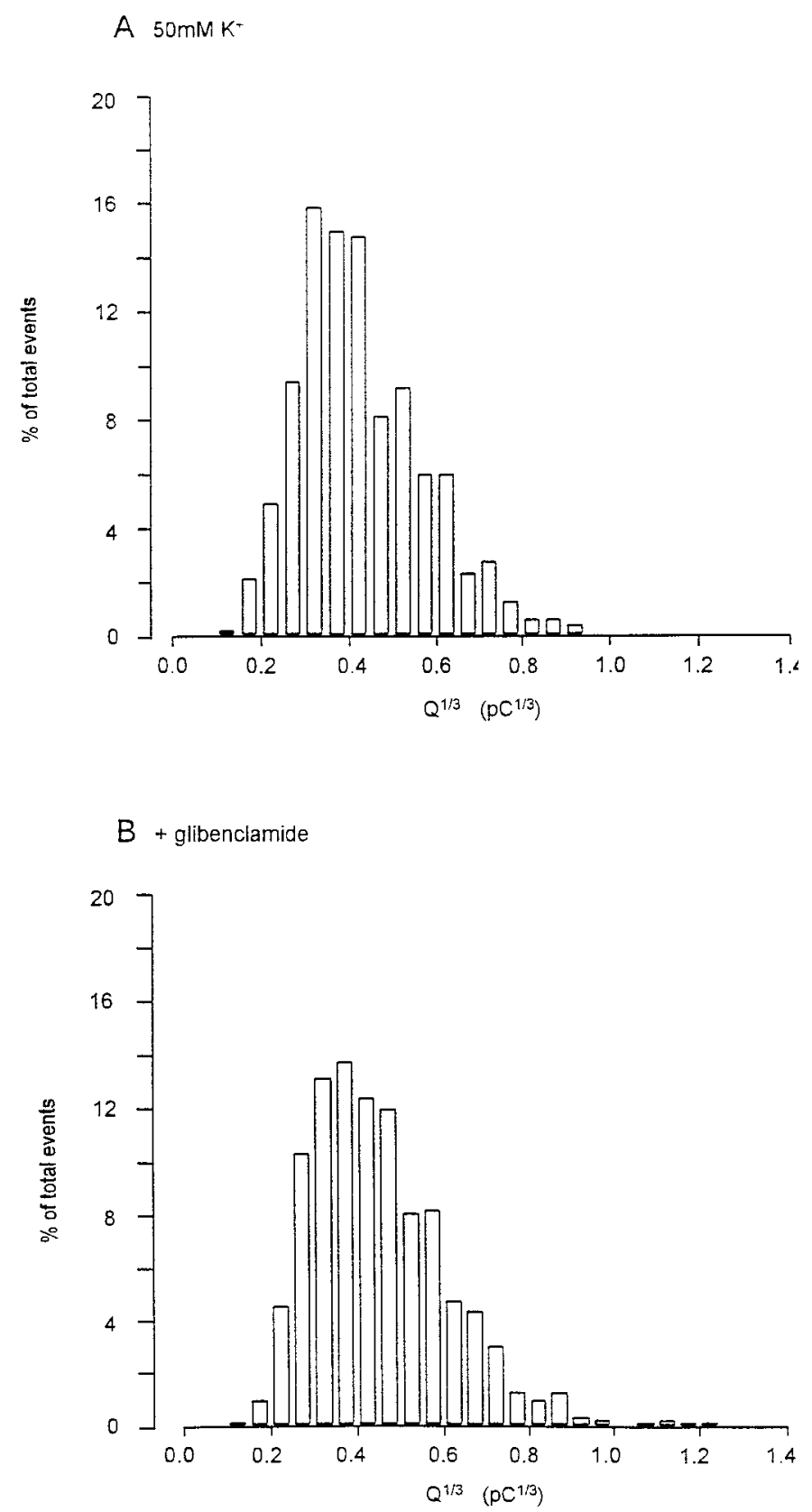

Figure 3. $A$, Plot of the percentage distribution of $Q^{1 / 3}$ determined from integration of 466 exocytotic events evoked from eight cells exposed to 50 $\mathrm{mm} \mathrm{K}^{+}$. $B$, Same as $A$, except that events (total 967) were recorded from eight cells exposed to $50 \mathrm{mM} \mathrm{K}^{+}$in the presence of $0.5 \mu \mathrm{M}$ glibenclamide.

The time course of exocytosis evoked by $50 \mathrm{~mm} \mathrm{~K}^{+}$is shown in Figure 2, which plots the mean cumulative number of events binned into $10 \mathrm{sec}$ periods for cells in the absence and presence of $0.5 \mu \mathrm{M}$ glibenclamide. Clearly, the rate of release of vesicles was enhanced in the presence of glibenclamide, but the pattern of release was similar; over the time period studied, secretion was sustained and continuous, as reflected in the near straight line cumulative increases in exocytotic event number.

A possible mechanism by which glibenclamide might enhance secretion is by stimulating the release of a distinct pool of catecholamine-containing vesicles. One way of investigating this is to integrate each electrochemical event to obtain charge $Q$, the 
Figure 4. Ongoing secretion evoked from two different PC -12 cells by exposure to solution containing $50 \mathrm{mM} \mathrm{K}^{+}$ and $0.5 \mu \mathrm{M}$ glibenclamide. For the periods indicated by the horizontal bars, $\mathrm{Ca}^{2+}$ was removed from the perfusate and replaced with $1 \mathrm{~mm}$ EGTA $(A)$, or $\mathrm{Cd}^{2+}(200 \mu \mathrm{M})$ was applied in the continued presence of $\mathrm{Ca}^{2+}(B)$.
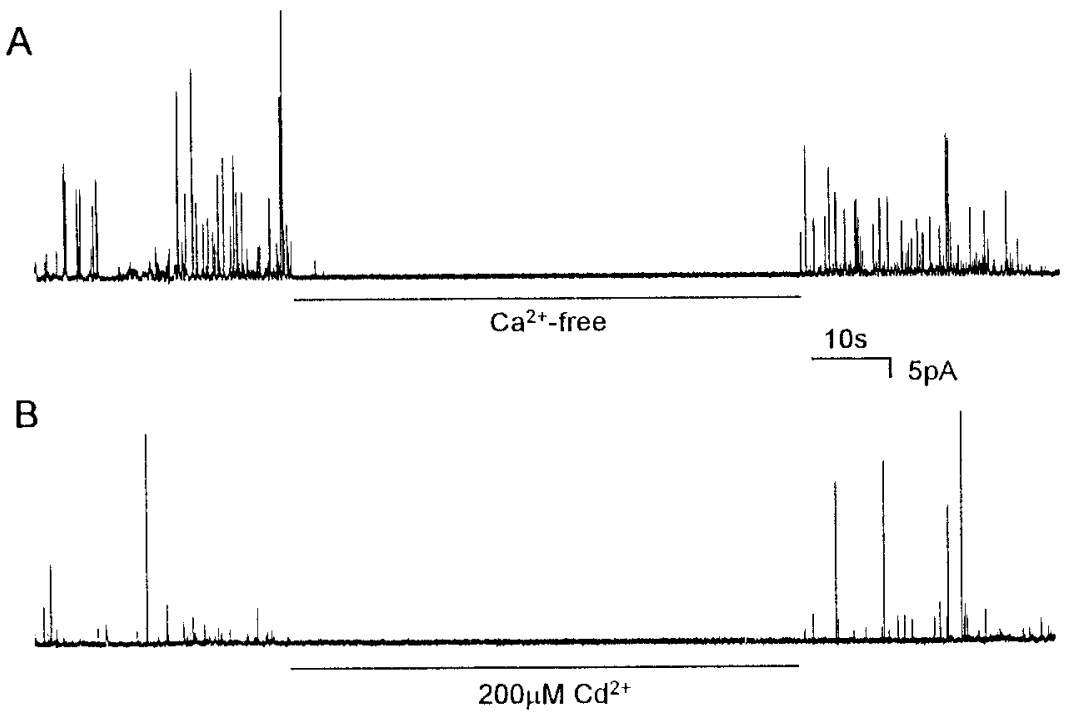

Figure 5. A, Microfluorimetric recordings from fura-2-loaded PC-12 cells. Shown is the $340: 380 \mathrm{~nm}$ fluorescence ratio in cells perfused for the periods indicated by the horizontal bars with a solution containing $50 \mathrm{~mm} \mathrm{~K}^{+}$in the absence (left) or presence (middle) of 0.5 $\mu \mathrm{M}$ glibenclamide. Right, Bar graph showing mean \pm SEM fluorescence changes evoked by $50 \mathrm{mM} \mathrm{K}^{+}$in the absence (open bar; $n=8$ ) or presence (hatched bar; $n=8$ ) of $0.5 \mu \mathrm{M}$ glibenclamide. $B$, Left, inward $\mathrm{Ca}^{2+}$ channel currents evoked in an example PC-12 cell by step depolarizations from -70 to $0 \mathrm{mV}$ before and during exposure to 0.5 $\mu \mathrm{M}$ glibenclamide, as indicated. Each trace is the mean of three currents evoked by successive step depolarizations before glibenclamide application and three currents evoked by successive step depolarizations in the presence of glibenclamide. Right, Current-voltage relationships evoked in another PC-12 cell by a ramp depolarization from -60 to $+60 \mathrm{mV}$ before and during exposure to $0.5 \mu \mathrm{M}$ glibenclamide, as indicated. Traces shown were obtained using conventional whole-cell recordings. A similar lack of effect of glibenclamide was observed using perforated-patch recordings.
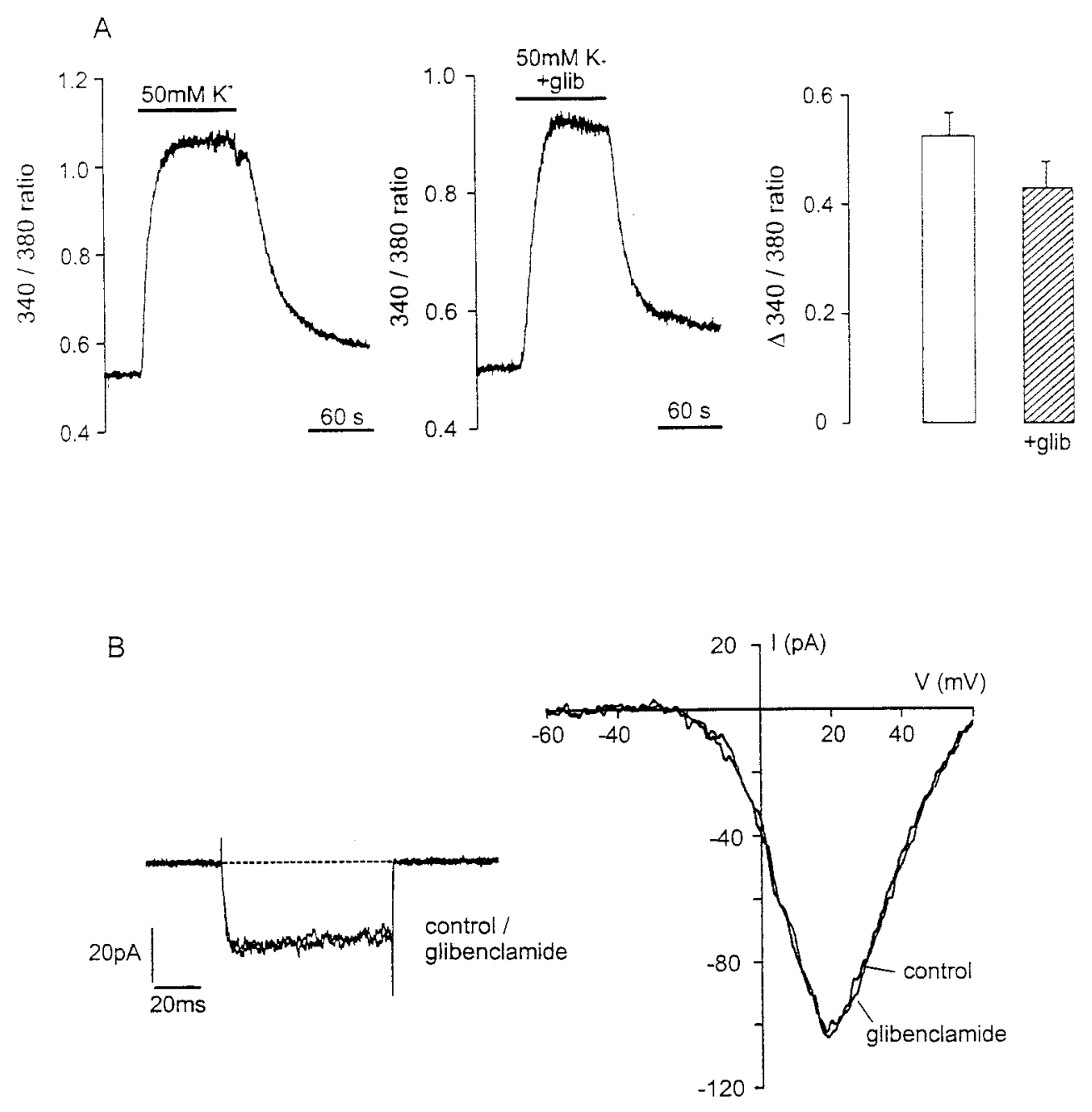

cube root of which is proportional vesicle size (see Materials and Methods). Figure 3 plots $Q^{1 / 3}$ for events evoked by $50 \mathrm{~mm} \mathrm{~K}^{+}$in the absence (Fig. $3 A$ ) and presence (Fig. $3 B$ ) of $0.5 \mu \mathrm{M}$ glibenclamide. In both cases, $Q^{1 / 3}$ values were normally distributed with a mean \pm SD of $0.43 \pm 0.15 \mathrm{pC}^{1 / 3}$ (determined from 466 events recorded from 9 cells) in the absence of glibenclamide and $0.45 \pm$
$0.16 \mathrm{pC}^{1 / 3}$ (967 events, 8 cells) in the presence of glibenclamide. The values obtained are in good agreement with previous studies in PC-12 cells (Finnegan et al., 1996), and vesicle size was clearly not affected by glibenclamide.

$\mathrm{K}^{+}$-evoked exocytosis from PC-12 cells is entirely dependent on $\mathrm{Ca}^{2+}$ influx through voltage-gated $\mathrm{Ca}^{2+}$ channels, because 

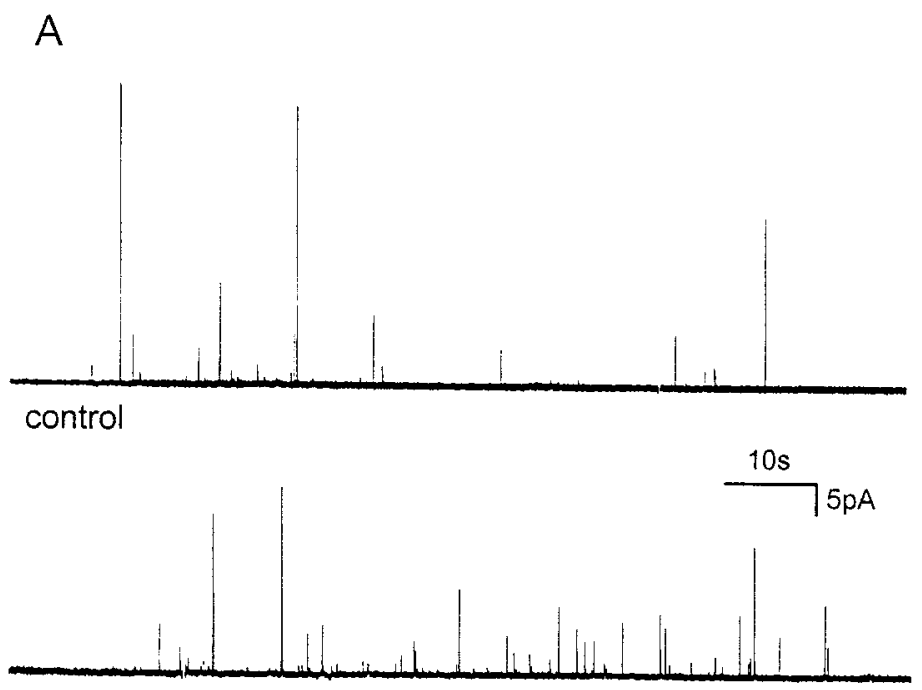

+ glibenclamide
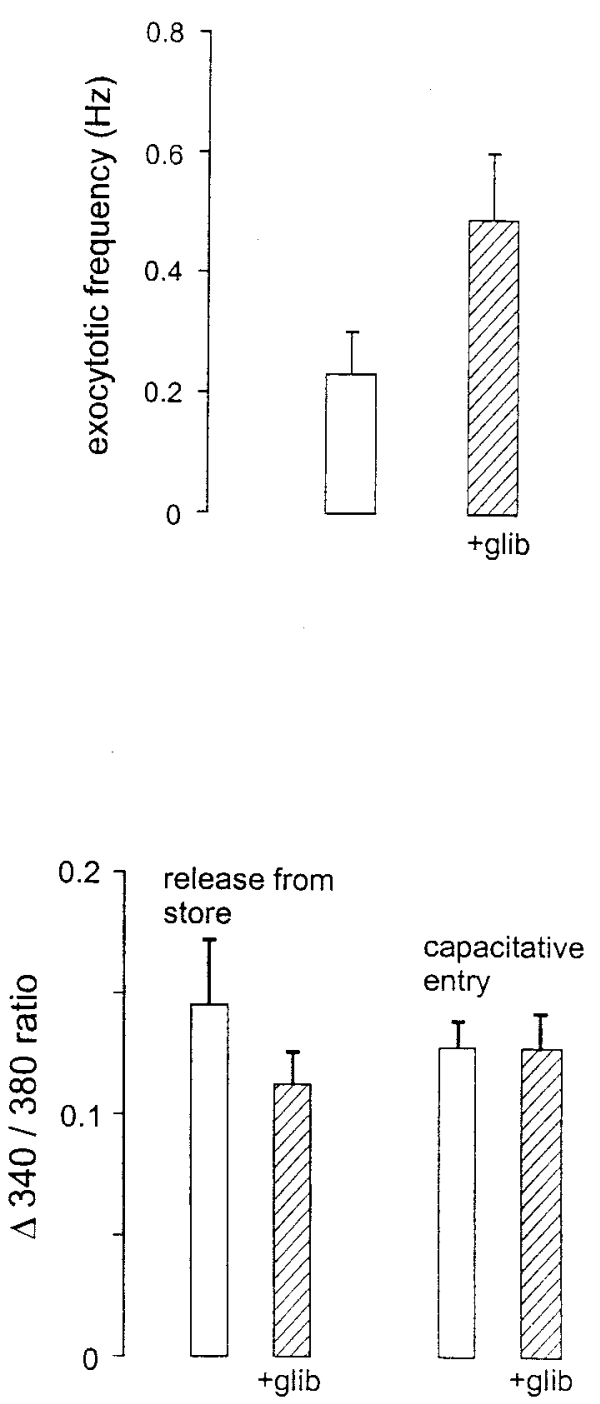

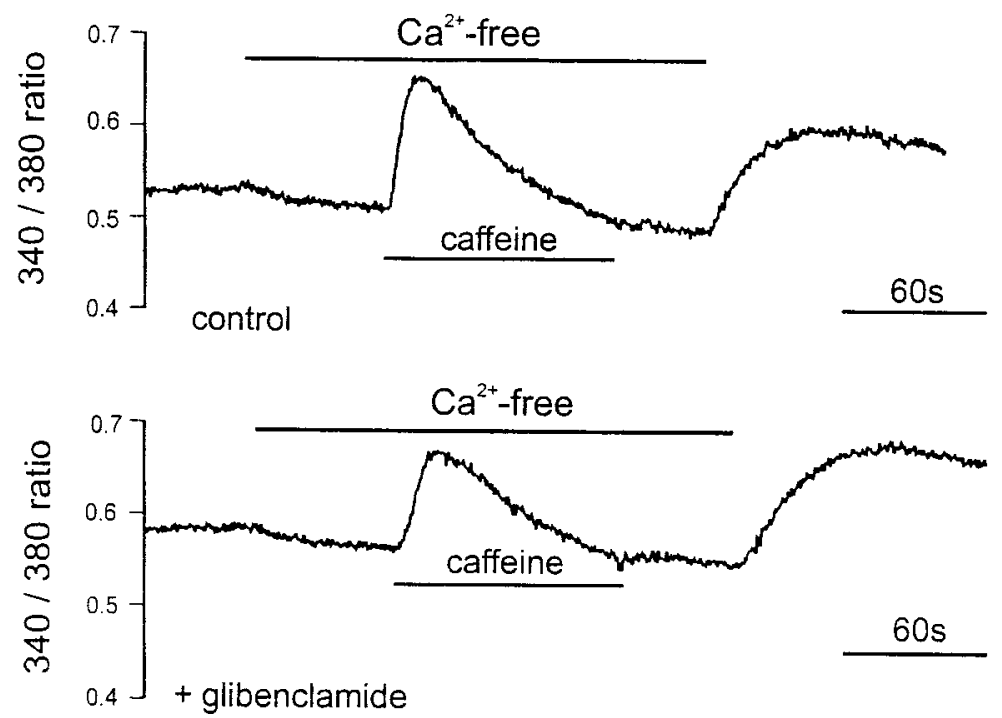

Figure 6. A, Left, Ongoing secretion evoked from two different PC-12 cells by exposure to $30 \mathrm{~mm}$ caffeine in the absence (top trace) or presence (bottom trace) of $0.5 \mu \mathrm{M}$ glibenclamide. Calibration applies to both traces. Right, Bar graph showing mean \pm SEM frequency of occurrence of exocytotic events evoked by $30 \mathrm{mM}$ caffeine in the absence (open bar; $n=14$ ) or presence (hatched bar; $n=13$ ) of $0.5 \mu \mathrm{M}$ glibenclamide. B, Left, Microfluorimetric recordings from fura-2-loaded PC-12 cells. Shown is the 340:380 nm fluorescence ratio in cells perfused for the periods indicated by the horizontal bars with a solution containing no added $\mathrm{Ca}^{2+}$ (plus $1 \mathrm{mM}$ EGTA) before, during, and after caffeine application $(30 \mathrm{mM})$. The transient rise of $\left[\mathrm{Ca}{ }^{2+}\right]_{\mathrm{i}}$ observed on exposure to caffeine was measured for the maximal release of $\mathrm{Ca}^{2+}$ from internal stores, as shown in the bar graph on the right. After washout of caffeine, $\mathrm{Ca}^{2+}$ was restored to the perfusate, and the resultant increase of fluorescence ratio reflects capacitative $\mathrm{Ca}{ }^{2+}$ entry. Recordings were made in the absence of glibenclamide (top trace) or in the presence of $0.5 \mu \mathrm{M}$ glibenclamide (bottom trace) (glibenclamide was added at the same time as switching to $\mathrm{Ca}^{2+}$-free medium and was present for the rest of the experiment). Right, Bar graph showing mean \pm SEM peak fluorescence changes evoked by $30 \mathrm{~mm}$ caffeine in $\mathrm{Ca}^{2+}$-free solution (release from store) and mean peak fluorescence seen after readmission of $\mathrm{Ca}^{2+}$ to the perfusate in the absence (open bars; $n=6$ ) or presence (hatched bars; $n=6$ ) of $0.5 \mu \mathrm{M}$ glibenclamide.

removal of external $\mathrm{Ca}^{2+}$ or bath application of the nonselective $\mathrm{Ca}^{2+}$ channel blocker $\mathrm{Cd}^{2+}$ completely prevented secretion evoked by $50 \mathrm{~mm} \mathrm{~K}^{+}$(Taylor and Peers, 1998). Figure 4 demonstrates that this was also the case when $\mathrm{K}^{+}$-evoked secretion was enhanced in the presence of glibenclamide; either removing external $\mathrm{Ca}^{2+}$ (and replacement with 1 mM EGTA) (Fig. 4A, representative of seven cells tested) or bath application of $\mathrm{Cd}^{2+}$ $(200 \mu \mathrm{M})$ (Fig. $4 B$, representative of eight cells tested) completely inhibited secretion. Thus, $\mathrm{K}^{+}$-evoked secretion in the presence of glibenclamide remained fully dependent on $\mathrm{Ca}^{2+}$ influx through voltage-gated $\mathrm{Ca}^{2+}$ channels.

One obvious means by which glibenclamide might potentiate 


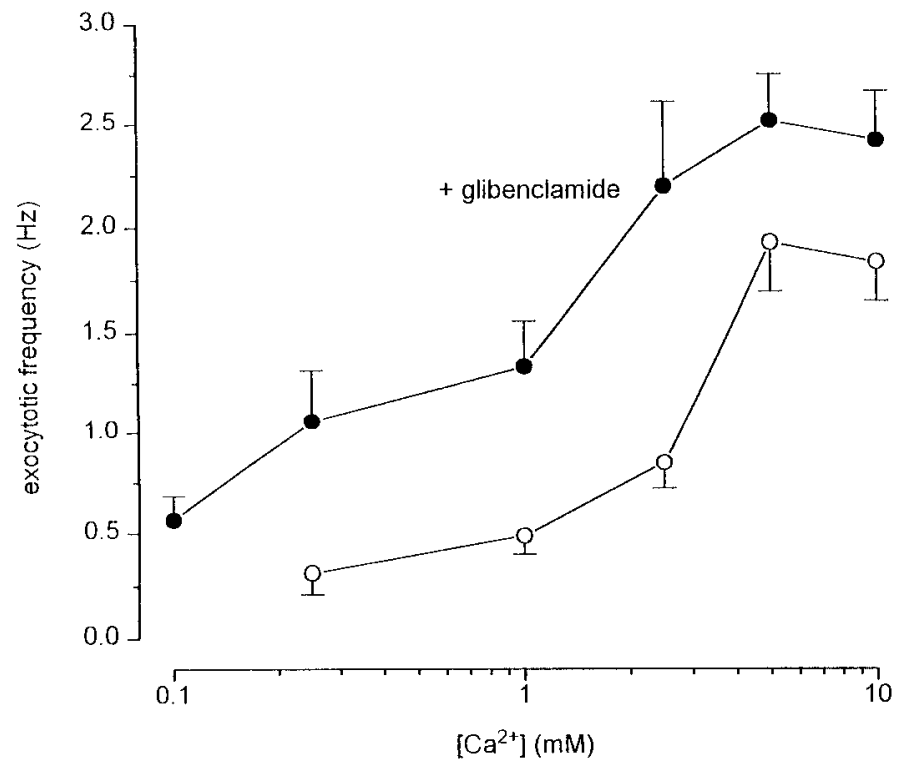

Figure 7. Plot of mean \pm SEM frequency of exocytosis evoked by $50 \mathrm{~mm}$ $\mathrm{K}^{+}$in the presence of a range of extracellular $\left[\mathrm{Ca}^{2+}\right]$ in the absence (open circles) or presence ( filled circles) of $0.5 \mu \mathrm{M}$ glibenclamide. Each point is the mean \pm SEM (error bars) exocytotic frequency and was determined from between 8 and 10 cells.

exocytosis could be via enhanced $\mathrm{Ca}^{2+}$ influx into PC-12 cells. To investigate this, we examined the rises of $\left[\mathrm{Ca}^{2+}\right]_{\mathrm{i}}$ (determined by ratiometric fluorescence from fura-2-loaded cells). As illustrated in Figure $5 A$, bath application of $50 \mathrm{~mm} \mathrm{~K}^{+}$produced a reversible rise of the $340: 380 \mathrm{~nm}$ ratio, indicating a rise of $\left[\mathrm{Ca}^{2+}\right]_{\mathrm{i}}$. Coapplication of $0.5 \mu \mathrm{M}$ glibenclamide with $50 \mathrm{~mm} \mathrm{~K}^{+}$ was without effect on these rises of $\left[\mathrm{Ca}^{2+}\right]_{\mathrm{i}}$ (Fig. $5 A$ ). To monitor the activity of voltage-gated $\mathrm{Ca}^{2+}$ channels more directly, we recorded whole-cell $\mathrm{Ca}^{2+}$ channel currents either conventionally $(n=4)$ or via the perforated-patch method $(n=3)$ using $20 \mathrm{~mm}$ $\mathrm{Ba}^{2+}$ as charge carrier. As illustrated in Figure $5 B$, glibenclamide $(0.5 \mu \mathrm{M})$ was without effect on these currents. In addition, perforated-patch recordings performed using perfusion and pipette solutions, which were designed not to inhibit $\mathrm{K}^{+}$channels (see Materials and Methods), revealed that the holding current required to clamp cells at $-70 \mathrm{mV}(-19.2 \pm 5.0 \mathrm{pA})$ was unaffected by $0.5 \mu \mathrm{M}$ glibenclamide $(-18.8 \pm 4.4 \mathrm{pA} ; n=6)$, indicative of a lack of depolarizing influence of glibenclamide. Thus, the enhancing effect of glibenclamide on exocytosis could not be accounted for by increased $\mathrm{Ca}^{2+}$ influx through voltage-gated $\mathrm{Ca}^{2+}$ channels.

A recent study has demonstrated that caffeine evokes catecholamine release from PC-12 cells via mobilization of $\mathrm{Ca}^{2+}$ from intracellular stores and the triggering of capacitative $\mathrm{Ca}^{2+}$ entry (CCE) (Koizume and Inoue, 1998). Figure 6A indicates that caffeine-evoked release is quantal (i.e., is attributable to exocytosis) and, like $\mathrm{K}^{+}$-evoked release, can be enhanced by glibenclamide. Release was observed using $30 \mathrm{~mm}$ caffeine because this has been shown to be a maximally effective concentration (Koizume and Inoue, 1998). These authors found that caffeine-evoked release was caused by $\mathrm{Ca}^{2+}$ influx via CCE, which is activated by $\mathrm{Ca}^{2+}$ release from intracellular stores rather than release from stores per se. Using microfluorimetric recordings, these two events can be separated using the experimental protocol shown in Figure $6 B$. Thus, when cells are perfused with $\mathrm{Ca}^{2+}$-free solutions, caffeine causes a transient rise of $\left[\mathrm{Ca}^{2+}\right]_{\mathrm{i}}$ because of the release from intracellular stores. When $2.5 \mathrm{mM} \mathrm{Ca}^{2+}$ is returned to the perfusate, a rise of $\left[\mathrm{Ca}^{2+}\right]_{i}$ is observed as a result of influx via $\mathrm{CCE}$, which was activated by the previous store depletion. Figure $6 B$ illustrates the finding that $0.5 \mu \mathrm{M}$ glibenclamide was completely without effect on $\mathrm{Ca}^{2+}$ release from internal stores or CCE observed after store depletion.

From the data presented in Figures 5 and 6, it is clear that glibenclamide cannot potentiate exocytosis via enhancement of $\mathrm{Ca}^{2+}$ influx or $\left[\mathrm{Ca}^{2+}\right]_{\mathrm{i}}$ levels during cell stimulation. We therefore considered the possibility that this sulfonylurea acts to sensitize the secretory apparatus to $\mathrm{Ca}^{2+}$. To investigate this, we examined the $\mathrm{Ca}^{2+}$ dependency of exocytosis evoked by $50 \mathrm{~mm}$ $\mathrm{K}^{+}$. Results are presented in Figure 7, which clearly shows that the relationship between exocytosis and extracellular $\mathrm{Ca}^{2+}$ is shifted leftward, indicating that glibenclamide does indeed enhance the $\mathrm{Ca}^{2+}$ sensitivity of exocytosis in these cells. A smaller increase in the plateau level of exocytosis was also seen when extracellular $\mathrm{Ca}^{2+}$ was raised to 5-10 mM, suggesting an increase in the pool of release-competent vesicles.

Despite the low concentrations of glibenclamide used in the present study, the possibility remains that the action of glibenclamide to potentiate exocytosis did not involve binding to its known pharmacological target, the SUR. To investigate this, we examined the actions of two activators of $\mathrm{K}_{\mathrm{ATP}}$ channels that are known to reverse the effects of glibenclamide by interfering allosterically with the binding of glibenclamide to SUR. The results presented in Figure $8 A$ demonstrate that the enhancing effect of glibenclamide on exocytosis evoked by $50 \mathrm{mM} \mathrm{K}^{+}$was inhibited by pinacidil and cromakalim, two structurally unrelated activators of $\mathrm{K}_{\text {АTP. }}$. Similarly, the enhanced secretion evoked by $30 \mathrm{~mm}$ caffeine was prevented by these activators (Fig. $8 B$ ). These findings strongly suggest that the effects of glibenclamide are mediated by a SUR.

\section{DISCUSSION}

The present study reports a potentiating effect of glibenclamide on quantal catecholamine secretion evoked from individual PC -12 cells by exposure to solutions containing either $50 \mathrm{mM} \mathrm{K}^{+}$ or $30 \mathrm{~mm}$ caffeine. Using either stimulus, this secretion is $\mathrm{Ca}^{2+}$ dependent. For $\mathrm{K}^{+}$-evoked release, $\mathrm{Ca}^{2+}$ influx through voltagegated $\mathrm{Ca}^{2+}$ channels is a prerequisite for exocytosis, and of the different channel types present in PC-12 cells (Liu et al., 1996), the N-type appear to be most closely coupled to depolarizationmediated release because $\omega$-conotoxin GVIA causes profound inhibition of such release (Taylor and Peers, 1998). Caffeine has recently been demonstrated to evoke secretion from PC-12 cells (Koizume and Inoue, 1998), and the present study indicates that this release is quantal (i.e., because of exocytosis) (Fig. 6). Caffeine causes release of $\mathrm{Ca}^{2+}$ from intracellular stores (presumably via activation of ryanodine receptors), and this store depletion in turn activates CCE. Koizume and Inoue (1998) recently demonstrated that most, if not all, caffeine-evoked release was attributable to CCE rather than release from stores per se. Thus, although both caffeine and elevated $\mathrm{K}^{+}$evoke quantal secretion of catecholamines, the underlying mechanisms are quite distinct.

The observation that glibenclamide potentiates release evoked by both stimuli suggests that it must act at a point in the stimulussecretion pathway that is common to both stimuli. Such a suggestion would discount the possibility that glibenclamide might act to enhance voltage-gated $\mathrm{Ca}^{2+}$ entry (because this is not involved in caffeine-evoked release), and this was demonstrated directly (Fig. $5 B$ ). The same reasoning would discount a potentiating effect of 
A $\mathrm{K}^{+}$-evoked secretion

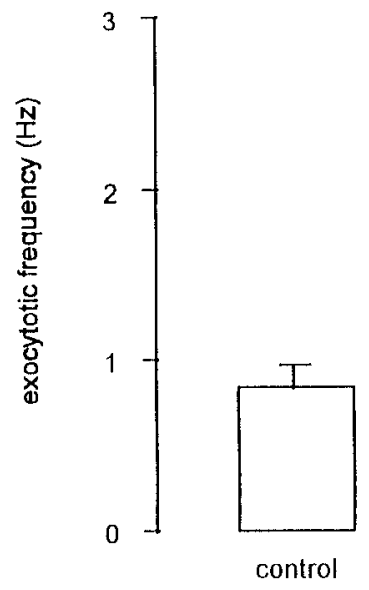

B caffeine-evoked secretion

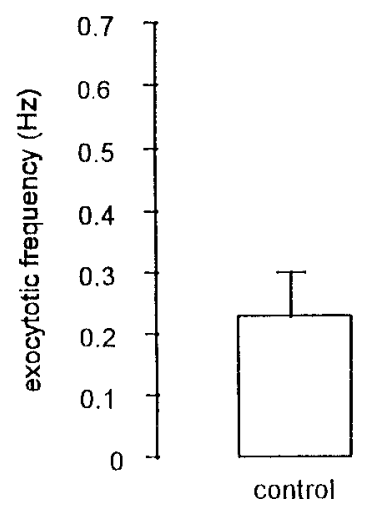

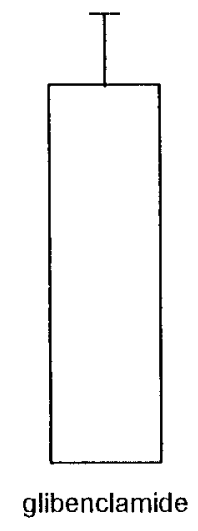

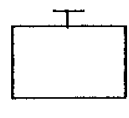

+ pinacidil

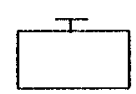

+ cromakalim

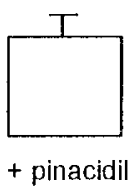

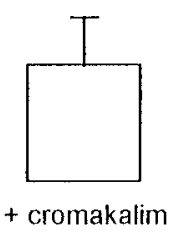

Figure 8. A, Bar graph showing mean exocytotic frequency evoked by $50 \mathrm{mM} \mathrm{K}^{+}$in the absence (control) or presence of $0.5 \mu \mathrm{M}$ glibenclamide applied alone or together with 10 $\mu \mathrm{M}$ pinacidil or $10 \mu \mathrm{M}$ cromakalim, as indicated. $B$, Bar graph showing mean exocytotic frequency evoked by $30 \mathrm{~mm}$ caffeine in the absence (control) or presence of $0.5 \mu \mathrm{M}$ glibenclamide applied alone or together with 10 $\mu \mathrm{M}$ pinacidil or $10 \mu \mathrm{M}$ cromakalim, as indicated. Each bar is the mean \pm SEM (error bars) exocytotic frequency and was determined from between 8 and 14 cells. glibenclamide on CCE, and this was also directly confirmed (Fig. $6 B)$. One possibility that might account for glibenclamide enhancement of secretion evoked by either stimulus would be via inhibition of $\mathrm{Ca}^{2+}$ extrusion mechanisms (plasmalemmal $\mathrm{Na}-\mathrm{Ca}$ exchange, $\mathrm{Ca}^{2+}$ ATPase, etc.). However, inhibition of $\mathrm{Ca}^{2+}$ extrusion would be expected to enhance the rise of $\left[\mathrm{Ca}^{2+}\right]_{i}$ caused by either stimulus, and we found that rises of $\left[\mathrm{Ca}^{2+}\right]_{\mathrm{i}}$ caused by either stimulus were unaffected by glibenclamide (Figs. $5 A, 6 B)$.

Several lines of evidence indicate that glibenclamide does not enhance exocytosis via inhibition of $\mathrm{K}_{\mathrm{ATP}}$ channels and hence membrane depolarization. First, and most directly, glibenclamide did not alter the holding current required to clamp cells at -70 $\mathrm{mV}$. Second, the degree of enhancement of exocytosis caused by glibenclamide (approximately threefold) was far greater than that caused by raising $\left[\mathrm{K}^{+}\right]$further from 50 to $100 \mathrm{~mm}$, which only causes an $\sim 1.3$-fold increase in exocytotic frequency (Taylor and Peers, 1998). Third, the rise of $\left[\mathrm{Ca}^{2+}\right]_{\mathrm{i}}$ caused by $50 \mathrm{~mm} \mathrm{~K}{ }^{+}$was unaffected by glibenclamide (Fig. $5 A$ ). Fourth, if glibenclamide had caused membrane depolarization, this would have decreased CCE induced by store depletion after caffeine application because the underlying channels are not voltage-gated (Parekh and Penner, 1997), and hence depolarization would reduce the driving force for $\mathrm{Ca}^{2+}$ entry via this route; this was unaffected (Fig. $6 B)$. Fifth, there is a notable lack of evidence for the presence of $\mathrm{K}_{\mathrm{ATP}}$ channels in PC-12 cells; a detailed analysis of $\mathrm{K}^{+}$channel types in these cells revealed the presence of four distinct $\mathrm{K}^{+}$ channel types, none of which were $\mathrm{K}_{\mathrm{ATP}}$ channels (Conforti and Millhorn, 1997). Furthermore, although cyanide causes hyperpolarization of PC-12 cells, this is unaffected by glibenclamide and is attributable instead to release of $\mathrm{Ca}^{2+}$ from internal stores and a consequent activation of $\mathrm{Ca}^{2+}$-dependent $\mathrm{K}^{+}$channels (Latha et al., 1994).

Recent studies have demonstrated that PC-12 cells and their chromaffin cell counterparts possess two pools of vesicles that can be distinguished in several ways (Bauerfeind et al., 1993; Kasai et al., 1996; Ninomiya et al., 1997; Kasai, 1999). One pool consists of small, synaptic-like vesicles, many of which are in a readily releasable state (i.e., will undergo exocytosis extremely rapidly after a rise of $\left.\left[\mathrm{Ca}^{2+}\right]_{\mathrm{i}}\right)$. Exocytosis of this pool can be enhanced by increasing the proportion of these vesicles, which are primed in a readily releasable state, without altering the $\mathrm{Ca}^{2+}$ dependence of exocytosis (Gillis et al., 1996). However, our present findings are unable to address the question of whether glibenclamide can increase the readily releasable pool of vesicles in PC-12 cells, because these vesicles exclusively contain acetylcholine (Bauerfeind et al., 1993; Kasai et al., 1996), which cannot be detected amperometrically. Our methodology only allows detection of quantal catecholamine release from PC-12 cells, which represent the second pool of larger, dense-cored vesicles in these cells (Kelly, 1993; Ninomiya et al., 1997; Kasai, 1999). The rate of release of this pool observed in the present study (Fig. 2) is in excellent agreement with previous reports, which used capacitance measurements (Kasai et al., 1996; Ninomiya et al., 1997). 
Glibenclamide clearly enhanced this rate of release (Figs. 1, 2), and from the estimates of quantal size (Fig. 3), it is most likely that glibenclamide promoted increased release from this same pool of vesicles in our studies.

Results presented in Figure 7 indicate that glibenclamide had a clear effect to enhance the $\mathrm{Ca}^{2+}$ dependence of exocytosis from PC-12 cells. The most striking feature was that glibenclamide caused a leftward shift (approximately threefold) in the $\mathrm{Ca}^{2+}$ dependency of release, which suggests that this sulfonylurea increases the $\mathrm{Ca}^{2+}$ sensitivity of exocytosis. In addition, at the highest $\mathrm{Ca}^{2+}$ concentrations studied (5 and $10 \mathrm{~mm}$ ), the secretory response was at or near saturation, and glibenclamide caused a modest $(\sim 1.3$-fold) increase in the plateau level of release. This can be interpreted as glibenclamide causing an increase in the number of release-competent catecholamine-containing vesicles. These two possible effects are not mutually exclusive, and of these, the former mechanism (i.e., increased $\mathrm{Ca}^{2+}$ sensitivity of secretion) appears to be the more dominant.

Glibenclamide is known to exert effects other than inhibition of $\mathrm{K}_{\mathrm{ATP}}$ channels in other systems. For example, it is a well known inhibitor of $\mathrm{Cl}^{-}$channels (Liu et al., 1998) and can also block $\mathrm{Ca}^{2+}$ channels in smooth muscle (Sadraei and Beech, 1995), as well as voltage-gated $\mathrm{K}^{+}$channels in a human neuroblastoma (Reeve et al., 1992). Additionally, glibenclamide has been suggested to bind to thromboxane $\mathrm{A}_{2}$ receptors in a speciesdependent manner (Kemp and McPherson, 1998). However, such nonspecific effects of glibenclamide are usually observed using high micromolar concentrations, and in no case have such effects been observed to be reduced or reversed by activators of $\mathrm{K}_{\mathrm{ATP}}$ channels.

Eliasson et al. (1996) have reported that sulfonylureas can potentiate secretion of insulin from pancreatic $\beta$ cells (mediated by $\mathrm{Ca}^{2+}$ influx through voltage-gated $\mathrm{Ca}^{2+}$ channels) via a mechanism that does not involve $\mathrm{K}_{\mathrm{ATP}}$ channel inhibition. These authors found these potentiating effects of sulfonylureas to be dependent on protein kinase $\mathrm{C}$ (PKC). A subsequent study failed to reproduce these findings (Garcia-Barrado et al., 1996). However, most recently, Tian et al. (1998) have indicated a potentiating effect on insulin secretion, but direct PKC activation was not involved. Although Eliasson et al. (1996) did not attempt to reverse the potentiating effects of sulfonylureas with $\mathrm{K}_{\mathrm{ATP}}$ activators, they speculated that SURs constituted a functional part of a regulatory exocytotic protein. Our results presented in Figure 8 strongly suggest that the enhancing effect of glibenclamide on exocytosis evoked by both $\mathrm{K}^{+}$and caffeine is mediated by a SUR; the actions of glibenclamide were reversed by cromakalim and pinacidil, two structurally distinct activators of $\mathrm{K}_{\mathrm{ATP}}$ that are known to interfere allosterically with the specific binding of glibenclamide (Bray and Quast, 1992). In neuronal tissue, these agents are also known to reverse the effects of glibenclamide (Schmid-Antomarchi et al., 1990). This evidence leads us to conclude that we have identified a novel role for SUR in modulating exocytosis in a neuronal tissue. Furthermore, our findings would suggest that this role is functionally downstream of $\mathrm{Ca}^{2+}$ entry or mobilization. The slight increased maximal secretory response (Fig. 7) is suggestive of an increase in a releasecompetent pool of vesicles, but this effect is much less than the leftward shift in the $\mathrm{Ca}^{2+}$ dependency of $\mathrm{K}^{+}$-evoked release (Fig. 7), which suggests a dominant "sensitizing" role for SUR of the secretory apparatus to $\mathrm{Ca}^{2+}$.

\section{REFERENCES}

Aguilar-Bryan,L, Clement JP, Gonzalez G, Kunjilwar K, Babenko A, Bryan J (1998) Toward understanding the assembly and structure of $\mathrm{K}_{\text {ATP }}$ channels. Physiol Rev 78:227-245.

Angleson JK, Betz WJ (1997) Monitoring secretion in real time: capacitance, amperometry and fluorescence compared. Trends Neurosci 20:281-287.

Ashford MLJ, Sturgess NC, Trout NJ, Gardner NJ, Hales CN (1988) Adenosine 5'-triphosphate-sensitive ion channels in neonatal rat cultured central neurones. Pflügers Arch 412:297-304.

Bauerfeind R, Regnier-Vigouroux A, Flatmark T, Huttner WB (1993) Selective storage of acetylcholine, but not catecholamines, in neuroendocrine synaptic-like microvesicles of early endosomal origin. Neuron 11:105-121.

Benndorf K, Thierfelder S, Doepner B, Gebhardt C, Hirche H (1997) Role of cardiac K-ATP channels during anoxia and ischemia. News Physiol Sci 12:78-83.

Bray KM, Quast U (1992) A specific binding site for $\mathrm{K}^{+}$channel openers in rat aorta. J Biol Chem 267:11689-11692.

Chow RH, Von Ruden L (1995) Electrochemical detection of secretion from single cells. In: Single channel recording (Sakmann B, Neher E, eds), pp 245-275. New York: Plenum.

Conforti L, Millhorn DE (1997) Selective inhibition of a slowinactivating voltage-dependent $\mathrm{K}^{+}$channel in rat PC12 cells by hypoxia. J Physiol (Lond) 502:293-305.

Duchen MR (1992) Fluorescence-monitoring cell chemistry in vivo. In: Monitoring neuronal activity: a practical approach (Stamford JA, ed), pp 231-260. Oxford: Oxford UP.

Eliasson L, Renstrom E, Ammala C, Berggren P-O, Bertorello AM, Bokvist K, Chibalin A, Deeney JT, Flatt PR, Gabel J, Gromada J, Larsson O, Lindstrom P, Rhodes CJ, Rorsman P (1996) PKCdependent stimulation of exocytosis by sulfonylureas in pancreatic $\beta$ cells. Science 271:813-815.

Finnegan JM, Pihel K, Cahill PS, Huang L, Zerby SE, Ewing AG, Kennedy RT, Wightman RM (1996) Vesicular quantal size measured by amperometry at chromaffin, mast, pheochromocytoma and pancreatic $\beta$ cells. J Neurochem 66:1914-1923.

Finta EP, Harms L, Sevick J, Fischer HD, Illes P (1993) Effects of potassium channel openers and their antagonists on rat locus coerulus neurones. Br J Pharmacol 109:308-315.

Garcia-Barrado MJ, Jonas JC, Gilon P, Henquin JC (1996) Sulphonylureas do not increase insulin secretion by a mechanism other that a rise in cytoplasmic $\mathrm{Ca}^{2+}$ in pancreatic $\beta$ cells. Eur $\mathrm{J}$ Pharmacol 298:279-286.

Gillis KD, Mossner R, Neher E (1996) Protein kinase C enhances exocytosis from chromaffin cells by increasing the size of the readily releasable pool of secretory granules. Neuron 16:1209-1220.

Hanson PI, Heuser JE, Jahn R (1997) Neurotransmitter release-four years of SNARE complexes. Curr Opin Neurobiol 7:310-315.

Kasai $\mathrm{H}$ (1999) Comparative biology of $\mathrm{Ca}^{2+}$-dependent exocytosis: implications of kinetic diversity for secretory function. Trends Neurosci 22:88-93.

Kasai H, Takagi H, Ninomiya Y, Kishimoto T, Ito K, Yoshida A, Yoshioka T, Miyashita Y (1996) Two components of exocytosis and endocytosis in phaeochromocytoma cells studied with caged $\mathrm{Ca}^{2+}$ compounds. J Physiol (Lond) 494:53-65.

Kelly RB (1993) Storage and release of neurotransmitters. Cell 72:45-53.

Kemp BK, McPherson GA (1998) Interspecies differences in thromboxane A2 receptors are distinguished by glibenclamide. Eur J Pharmacol 354:173-178.

Koizume S, Inoue K (1998) Functional coupling of secretion and capacitative calcium entry in PC12 cells. Biochem Biophys Res Commun 244:293-297.

Latha MV, Borowitz JL, Yim GK, Kanthasamy A, Isom GE (1994) Plasma membrane hyperpolarization by cyanide in chromaffin cells: role of potassium channels. Arch Toxicol 68:370-374.

Lee K, Brownhill V, Richardson PJ (1997) Antidiabetic sulphonylureas stimulate acetylcholine release from striatal cholinergic interneurones through inhibition of K(ATP) channel activity. J Neurochem 69:1774-1776.

Liu H, Gurnett CA, De Waard M, Witcher DR, Campbell KP (1996) 
Expression and subunit interaction of voltage-dependent $\mathrm{Ca}^{2+}$ channels in PC12 cells. J Neurosci 16:7557-7565.

Liu Y, Oiki S, Tsumura T, Shimizu T, Okada Y (1998) Glibenclamide blocks volume-sensitive $\mathrm{Cl}^{-}$channels by dual mechanisms. Am J Physiol 275:C343-C351.

Murphy KP, Greenfield SA (1992) Neuronal selectivity of ATP-sensitive potassium channels in guinea-pig substantia nigra revealed by responses to anoxia. J Physiol (Lond) 453:167-183.

Ninomiya Y, Kishimoto T, Yamazawa T, Ikeda H, Miyashita Y, Kasai H (1997) Kinetic diversity in the fusion of exocytotic vesicles. EMBO J 16:929-934.

Noma A (1983) ATP-regulated single K channels in cardiac muscle. Nature 305:147-148.

Parekh AB, Penner R (1997) Store depletion and calcium influx. Physiol Rev 77:901-930.

Pierrefiche O, Bischoff AM, Richter DW (1996) ATP-sensitive $\mathrm{K}^{+}$ channels are functional in expiratory neurones of normoxic cats. J Physiol (Lond) 494:399-409.

Reeve HL, Vaughan PFT, Peers C (1992) Glibenclamide inhibits a voltage-gated $\mathrm{K}^{+}$current in the human neuroblastoma cell line $\mathrm{SH}$ SY5Y. Neurosci Lett 135:137-140.

Sadraei H, Beech DJ (1995) Ionic currents and inhibitory effects of glibenclamide in seminal vesicle smooth muscle cells. Br J Pharmacol 115:1447-1454.

Schmid-Antomarchi H, Amoroso S, Fosset M, Lazdunski M (1990) $\mathrm{K}^{+}$ channel openers activate brain sulphonylurea-sensitive $\mathrm{K}^{+}$channels and block neurosecretion. Proc Natl Acad Sci USA 87:3489-3492.

Sudhof T (1995) The synaptic vesicle: a cascade of protein-protein interactions. Nature 375:645-653.

Takashima A, Koike T (1985) Relationship between dopamine content and its secretion in PC12 cells as a function of cell growth. Biochem Biophys Acta 847:101-107.

Taylor SC, Peers C (1998) Hypoxia evokes catecholamine secretion from rat pheochromocytoma PC-12 cells. Biochem Biophys Res Commum 248:13-17.

Tian YA, Johnson G, Ashcroft SJ (1998) Sulphonylureas enhance exocytosis from pancreatic $\beta$-cells by a mechanism that does not involve direct activation of protein kinase C. Diabetes 47:1722-1726.

Tischler AS, Perlman RL, Morse GM, Sheard BE (1983) Glucocorticoids increase catecholamine synthesis and storage in PC-12 pheochromocytoma cell cultures. J Neurochem 40:364-370.

Wu CW, Leung CK, Yung WH (1996) Sulphonylureas reverse hypoxia induced $\mathrm{K}^{+}$conductance increase in substantia nigra pars reticulata neurones. NeuroReport 7:2513-2517. 